\title{
Metabolism of Alcaligenes denitrificans in biofilm vs planktonic cells
}

\author{
P. Teixeira and R. Oliveira \\ Centro de Engenharia Biológica - IBQF, Universidade do Minho, Braga, Portugal
}

2001/149: received 21 June 2001, revised 7 August 2001 and accepted 15 August 2001

P. TEIXEIRA AND R. OLIVEIRA. 2002.

Aims: To compare the effect of phosphorous concentration $\left(200 \mathrm{mg} \mathrm{P}^{-1}\right.$ and $\left.20 \mathrm{mg} \mathrm{P}^{-1}\right)$ on the denitrifying efficiency of Alcaligenes denitrificans when in the form of planktonic cells or in the form of a biofilm, and to select the most adequate $\mathrm{C} / \mathrm{N}$ ratio.

Methods and Results: Two types of assays were carried out: with planktonic cells and with cells in biofilm form. Anoxic bottles with the appropriate $\mathrm{C} / \mathrm{N}$ and phosphorous concentration were incubated at $30^{\circ} \mathrm{C}$ and submitted to orbital shaking at $150 \mathrm{rev} \mathrm{min}^{-1}$. The specific activity of cells in biofilm form, in terms of substrate consumption, was significantly higher than cells in planktonic form. With regard to the effect of increasing phosphorous concentration, an increase in specific activity was also only evident when the cells were in biofilm form.

Conclusions: The two forms showed different performances and phosphorous concentration only markedly affected the biofilm form.

Significance and Impact of the Study: The importance of the C/N/P ratio in the denitrification process is demonstrated. As there was no report in the literature about the stoichiometric relationship of heterotrophic denitrification with citrate, its stoichiometry, including the requirement for cell synthesis, was determined.

\section{INTRODUCTION}

Denitrification is a process by which nitrate is reduced via nitrite to nitrous oxide and, finally, to harmless nitrogen gas. Accumulation of its intermediates is undesirable as they are toxic. As most denitrifying bacteria are heterotrophic, an organic carbon source is required. Several carbon sources have been used, including methanol, acetate, propionate, acetic acid, glucose, benzoic acid etc. As, in the last few years it has become important to use carbon sources compatible with the standards imposed for drinking water, acetate and citrate are being increasingly used. Blaszczyk (1983) found that in a packed bed reactor working with acetate, denitrifying bacteria were dominated by Pseudomonas aeruginosa, which is pathogenic. Therefore, in this work, citrate was chosen as carbon source and the stoichiometry of denitrification, including the requirement for cell synthesis, using it as carbon source was determined. Although the stoichiometric relationships of heterotrophic denitrification with various carbonaceous

Correspondence to: Rosário Oliveira, Centro de Engenharia Biológica, Universidade do Minho, Campus de Gualtar, 4710-057 Braga, Portugal (e-mail: roliveira@deb.uminho.pt). substrates have been referred to in the literature (Gayle et al. 1989; Mateju et al. 1992), citrate has not been described.

All bacterial reactions (except photosynthesis) are the result of a synthesis of biomass reaction and an energy production reaction, being both oxidation-reduction reactions. Considering denitrification as a two-step process, and using citrate as the carbon and energy source, the following reactions can be written:

$$
\begin{array}{r}
\text { First step: } 9 \mathrm{NO}_{3}^{-}+\mathrm{C}_{6} \mathrm{H}_{5} \mathrm{O}_{7}^{3-}+3 \mathrm{H}^{+} \\
=4 \mathrm{H}_{2} \mathrm{O}+6 \mathrm{CO}_{2}+9 \mathrm{NO}_{2}^{-} \\
\text {Second step: } 18 \mathrm{NO}_{2}^{-}+\mathrm{C}_{6} \mathrm{H}_{5} \mathrm{O}_{7}^{3-}+57 \mathrm{H}^{+} \\
=31 \mathrm{H}_{2} \mathrm{O}+6 \mathrm{CO}_{2}+9 \mathrm{~N}_{2}
\end{array}
$$

Overall energy equation:

$$
\begin{array}{r}
\mathrm{NO}_{3}^{-}+0 \cdot 1667 \mathrm{C}_{6} \mathrm{H}_{5} \mathrm{O}_{7}^{3-}+3 \cdot 5 \mathrm{H}^{+} \\
=2 \cdot 1667 \mathrm{H}_{2} \mathrm{O}+\mathrm{CO}_{2}+0 \cdot 5 \mathrm{~N}_{2}
\end{array}
$$

Although this equation reveals the stoichiometric quantity of citrate needed for nitrate removal, in practice, additional citrate is required for cell synthesis. The cell synthesis equation is the sum of the following oxidation-reduction equations: 
Oxidation equation:

$$
\mathrm{C}_{6} \mathrm{H}_{5} \mathrm{O}_{7}^{3-}+5 \mathrm{H}_{2} \mathrm{O}=6 \mathrm{CO}_{2}+15 \mathrm{H}^{+}+18 \mathrm{e}^{-}
$$

Reduction equation:

$$
\begin{aligned}
& 0.1786 \mathrm{CO}_{2}+0.0357 \mathrm{NO}_{3}^{-}+1.0357 \mathrm{H}^{+}+\mathrm{e}^{-} \\
& =0.3929 \mathrm{H}_{2} \mathrm{O}+0.0357 \mathrm{C}_{5} \mathrm{H}_{7} \mathrm{O}_{2} \mathrm{~N}
\end{aligned}
$$

Thus, the cell synthesis overall equation is:

$$
\begin{aligned}
& \mathrm{C}_{6} \mathrm{H}_{5} \mathrm{O}_{7}^{3-}+0.6426 \mathrm{NO}_{3}^{-}+3.6426 \mathrm{H}^{+} \\
& \quad=2 \cdot 7852 \mathrm{CO}_{2}+2 \cdot 0722 \mathrm{H}_{2} \mathrm{O}+0.6426 \mathrm{C}_{5} \mathrm{H}_{7} \mathrm{O}_{2} \mathrm{~N}
\end{aligned}
$$

McCarty et al. (1969) defined the consumptive ratio (Cr) as the ratio of the total quantity of an organic chemical consumed during denitrification to the stoichiometric requirement for denitrification and deoxygenation alone. A consumptive ratio of one indicates that no chemical is required for cell synthesis. Consequently, the consumptive ratio is experimentally observed to be greater than one. The average value proposed by these authors is $1 \cdot 3 \pm 0 \cdot 06$.

If equation 6 is multiplied by 0.39 and added to equation 3 , an equation is obtained in which the ratio of equivalents of citrate to equivalents of nitrate-nitrogen will equal the consumptive ratio of $1 \cdot 3$. Normalizing this equation to one mole of nitrate, the overall denitrification equation is:

$$
\begin{array}{r}
\mathrm{NO}_{3}^{-}+0.361 \mathrm{C}_{6} \mathrm{H}_{5} \mathrm{O}_{7}^{3-}+2 \cdot 083 \mathrm{H}^{+}=1 \cdot 84 \mathrm{CO}_{2} \\
+1 \cdot 716 \mathrm{H}_{2} \mathrm{O}+0.065 \mathrm{C}_{5} \mathrm{H}_{7} \mathrm{O}_{2} \mathrm{~N}+0.467 \mathrm{~N}_{2}
\end{array}
$$

Besides the requirement of carbon, the availability of phosphorous (usually as phosphate) is a key parameter in microbial growth. For economic reasons, and in order to prevent an excessive suspended biomass growth and to avoid eutrophication, it is important to study the optimal concentration of phosphate necessary to the denitrification process.

Although in the past decade there has been an explosion of new technologies to elucidate the structure of biofilms, such as the confocal laser scanning microscope together with digital image analysis (Caldwell et al. 1992) and microsensors, little attention has been paid to the physiological behaviour of the microbial cells. In fact, there is evidence that the behaviour of micro-organisms is different when immobilized on a surface (biofilm form) and in the aqueous phase (planktonic form). Marshall and Goodman (1994) suggested that differences experienced by bacteria at surfaces may alter the expression of certain genes in either a positive or negative manner and hence, may alter the overall physiological characteristics of the immobilized organisms. McFeters et al. (1990) reported that bacteria attached to sand particles had a shorter lag time and higher specific activity in the degradation of nitrilotriacetate than bacteria in the bulk aqueous phase. Vandevivere and Kirchman (1993) have shown that exopolymer production by bacterial cells is stimulated at a solid surface. A Pseudomonas sp. formed long filamentous cells when grown as a biofilm on solid surfaces, whereas cells grown on agar plates or in liquid were normal rods, about $1 \mu \mathrm{m}$ long (McCoy and Costerton 1982). In view of this evidence, it seemed important to investigate whether the behaviour of the cells in liquid medium could be extrapolated to the cells in a biofilm.

The aim of this work was to compare the effect of phosphorous concentration on the denitrifying efficiency of Alcaligenes denitrificans when in the form of planktonic cells or in the form of a biofilm, and to select the most adequate $\mathrm{C} / \mathrm{N}$ ratio.

\section{MATERIALS AND METHODS}

\section{Bacterial strain and culture medium}

The bacterium used in this study was Alcaligenes denitrificans ATCC 15173, grown in medium containing $0.2448 \mathrm{~g}$ $\mathrm{C}_{6} \mathrm{H}_{5} \mathrm{Na}_{3} \mathrm{O}_{7} .2 \mathrm{H}_{2} \mathrm{O}, 0.289 \mathrm{~g} \mathrm{KNO}_{3}, 0.93 \mathrm{~g} \mathrm{~K}_{2} \mathrm{HPO}_{4}, 0.18 \mathrm{~g}$ $\mathrm{KH}_{2} \mathrm{PO}_{4}, 0.0242 \mathrm{~g} \mathrm{NaMoO} .2 \mathrm{H}_{2} \mathrm{O}, 0.0056 \mathrm{~g} \mathrm{FeSO}_{4} .7 \mathrm{H}_{2} \mathrm{O}$, $0 \cdot 00081 \mathrm{~g} \mathrm{MnCl} 2.2 \mathrm{H}_{2} \mathrm{O}, 0.0515 \mathrm{~g} \mathrm{CaCl} 2.2 \mathrm{H}_{2} \mathrm{O}$ and $0.4092 \mathrm{~g}$ $\mathrm{MgSO}_{4} .7 \mathrm{H}_{2} \mathrm{O}$ in 1 litre of distilled water. The cultures were grown in batch for 3 days at $30^{\circ} \mathrm{C}$ and orbital shaking at $150 \mathrm{rev} \mathrm{min}^{-1}$.

\section{Media}

For a carbon/nitrogen ratio of 2 , the experiments with cells in the planktonic form and in the form of biofilm were performed with a medium containing: $408 \mathrm{mg}{ }^{-1} \mathrm{C}_{6} \mathrm{H}_{5} \mathrm{Na}_{3} \mathrm{O}_{7} \cdot 2 \mathrm{H}_{2} \mathrm{O}$, $360.9 \mathrm{mg} \mathrm{l}^{-1} \mathrm{KNO}_{3}, 24 \cdot 2 \mathrm{mg} \mathrm{l}^{-1} \mathrm{NaMoO}_{4} .2 \mathrm{H}_{2} \mathrm{O}, 5.6 \mathrm{mg} \mathrm{l}^{-1}$ $\mathrm{FeSO}_{4} .7 \mathrm{H}_{2} \mathrm{O}, 0.81 \mathrm{mg} \mathrm{l^{-1 }} \mathrm{MnCl}_{2} .2 \mathrm{H}_{2} \mathrm{O}, 51.5 \mathrm{mg} \mathrm{l} \mathrm{l}^{-1}$ $\mathrm{CaCl}_{2} \cdot 2 \mathrm{H}_{2} \mathrm{O}, 409 \cdot 2 \mathrm{mg} \mathrm{l}^{-1} \mathrm{MgSO}_{4} \cdot 7 \mathrm{H}_{2} \mathrm{O}$, and a variable concentration of $\mathrm{K}_{2} \mathrm{HPO}_{4}$ and $\mathrm{KH}_{2} \mathrm{PO}_{4}$, in order to obtain two different concentrations (200 and $20 \mathrm{mg} \mathrm{P}^{-1}$ ). In the case of the experiments with a $\mathrm{C} / \mathrm{N}=3,612.2 \mathrm{mg} \mathrm{l}^{-1}$ $\mathrm{C}_{6} \mathrm{H}_{5} \mathrm{Na}_{3} \mathrm{O}_{7} .2 \mathrm{H}_{2} \mathrm{O}$ and $360 \cdot 9 \mathrm{mg}{ }^{-1} \mathrm{KNO}_{3}$ were used. Due to the buffering capacity of the medium, no $\mathrm{pH}$ adjustment was made.

\section{Planktonic cells assays}

The assays were carried out in $160 \mathrm{ml}$ flasks containing $90 \mathrm{ml}$ of the culture medium with the appropriate $\mathrm{C} / \mathrm{N}$ and phosphorous concentration. Each flask was inoculated with $2.5 \mathrm{ml}$ of the stock cell suspension, and anoxic conditions were ensured by flushing the bottles with helium and immediately sealing them. All bottles were incubated at $30^{\circ} \mathrm{C}$ and submitted to orbital shaking at $150 \mathrm{rev} \mathrm{min}^{-1}$. All assays were carried out in duplicate. Aliquots of $2 \mathrm{ml}$ of each bottle were taken every hour and immediately analysed. Biomass was calculated by optical density at $660 \mathrm{~nm}$. 
Samples were then filtered through $0 \cdot 2 \mu \mathrm{m}$ syringe filters and the filtrates used for nitrate, citrate and nitrite determinations. At the end of each experiment, the volume of liquid remaining was measured and used to determine total and volatile solids.

\section{Biofilm formation}

Biofilms of Alc. denitrificans were produced in an anoxic rotating biological contactor, consisting of 13 polymethyl methacrylate discs (diameter $=23.4 \mathrm{~cm}$ ) and a hood in a single stage, with a total volume of $15.5 \mathrm{l}$. The rotational speed was 2 rev $\min ^{-1}$ and the temperature was maintained at around $30^{\circ} \mathrm{C}$ by means of a water bath. The reactor was operated with a hydraulic retention time of $2 \mathrm{~h}$, and was inoculated with $600 \mathrm{ml}$ of a pure culture of Alc. denitrificans. For the initial formation and accumulation of the biofilm, the reactor was operated in batch mode for a week. After this period, it was fed continuously with the synthetic medium described above.

\section{Activity of biofilm}

The assessment of biofilm activity was performed by inoculating $150 \mathrm{ml}$ of the feeding medium, in a $250 \mathrm{ml}$ Schott flask, with a known amount of biofilm. The biofilm samples to be used as inocula were removed from the first, seventh and thirteenth discs in order to evaluate the activity along the reactor. All the assays were duplicated. The flasks were incubated in an orbital shaker at $26^{\circ} \mathrm{C}$ and $150 \mathrm{rev} \mathrm{min}^{-1}$. The consumption of substrate (nitrate and citrate) was followed with time.

\section{Analytical methods}

Citrate and nitrate concentrations were measured by HPLC (Jasco, Tokyo, Japan) in an organic acids column (Chrompack, $300 \mathrm{~mm} \times 6.5 \mathrm{~mm}$; Varian Inc., Middleburg, The Netherlands). Nitrite was determined by a colorimetric method using $\mathrm{N}$-(1-naphthyl)-ethylene-diamine, according to the Standard Methods of Analysis (APHA 1995). For the determination of nitrite, nitrate and citrate ions, the sample was filtered through a $0 \cdot 2 \mu \mathrm{m}$ membrane filter to remove the interference of suspended particles. Total solids (TS) were also determined in accordance with the Standard Methods of Analysis (APHA 1995).

\section{RESULTS}

According to stoichiometry, the quantity of citrate needed for nitrate removal and for cell synthesis gives a carbon/ nitrogen ratio $(\mathrm{C} / \mathrm{N})$ of 1.86 . However, some citrate is necessary for the deoxygenation of the medium (McCarty et al. 1969). Therefore, in this work, two $\mathrm{C} / \mathrm{N}$ ratios were studied (2 and 3 ).

It is well known that in addition to carbon and nitrogen, phosphate is an essential element for bacterial growth. An insufficient phosphate level leads to nitrite accumulation (Reisinger et al. 1989). As phosphate concentration significantly affects denitrifying efficiency and it is difficult to find information on its optimal value, it was decided to assay two phosphorous concentrations: 200 and $20 \mathrm{mg} \mathrm{P} \mathrm{l}^{-1}$. The first level was selected based on a study performed in a chemostat with a different denitrifying strain, Alcaligenes faecalis, using a phosphorous concentration of $211 \mathrm{mg} \mathrm{l}^{-1}$ (Robertson et al. 1989). However, assuming that $200 \mathrm{mg} \mathrm{P}^{-1}$ could lead to excessive biomass growth, a 10 -fold smaller phosphorous concentration $\left(20 \mathrm{mg} \mathrm{P} \mathrm{l}^{-1}\right)$ was also assayed.

The results of the denitrifying activity experiments with cells of Alc. denitrificans in planktonic form, for the two $\mathrm{C} / \mathrm{N}$ ratios, are presented in Figs 1 and 2.

The assays for $\mathrm{C} / \mathrm{N}=3$ continued for $17 \mathrm{~h}$. All the nitrate was consumed in $16 \mathrm{~h}$ and the specific nitrate consumption rate was similar for both phosphorous concentrations. Citrate consumption was, on average, only $35 \%$, although the uptake rates were similar to those obtained for $\mathrm{C} / \mathrm{N}=2$. This means that there was an over-addition of carbon, which, for economic and environmental reasons, is not advisable. For $\mathrm{C} / \mathrm{N}=2$, the assays continued for $28 \mathrm{~h}$. At the end of this time, and for both phosphorous concentrations, all the nitrate had been consumed. All the citrate was consumed in the assays with $200 \mathrm{mg} \mathrm{P} \mathrm{^{-1 }}$ whereas, on average, only $78.5 \%$ was consumed in the

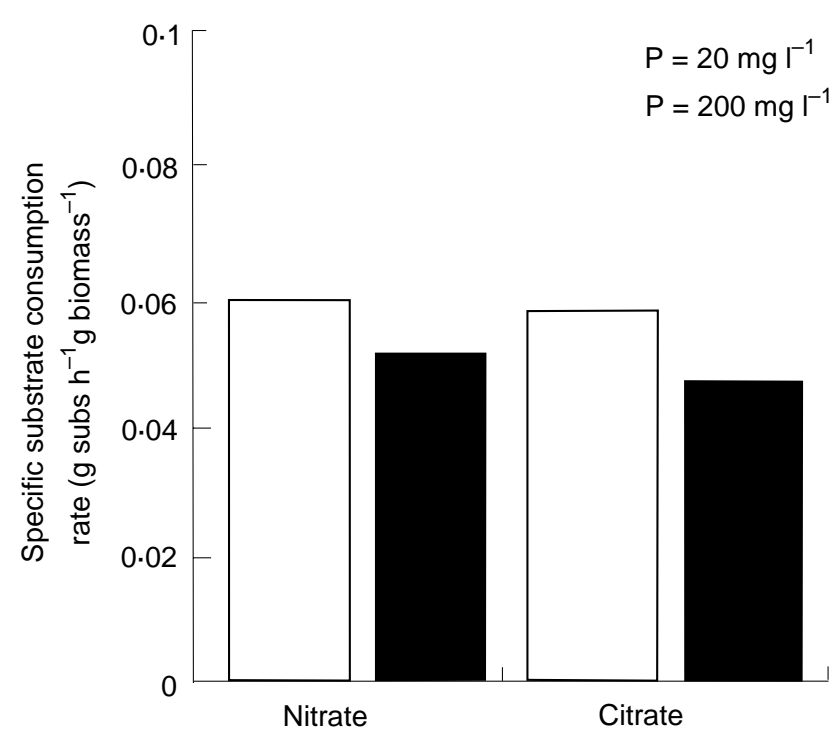

Fig. 1 Specific substrate consumption of planktonic cells of Alcaligenes denitrificans for $\mathrm{C} / \mathrm{N}=3$ and under two phosphorous concentrations: $(\square), \mathrm{P}^{-}=20 \mathrm{mg} \mathrm{l}^{-1} ;(\square), \mathrm{P}=200 \mathrm{mg} \mathrm{l}^{-1}$ 


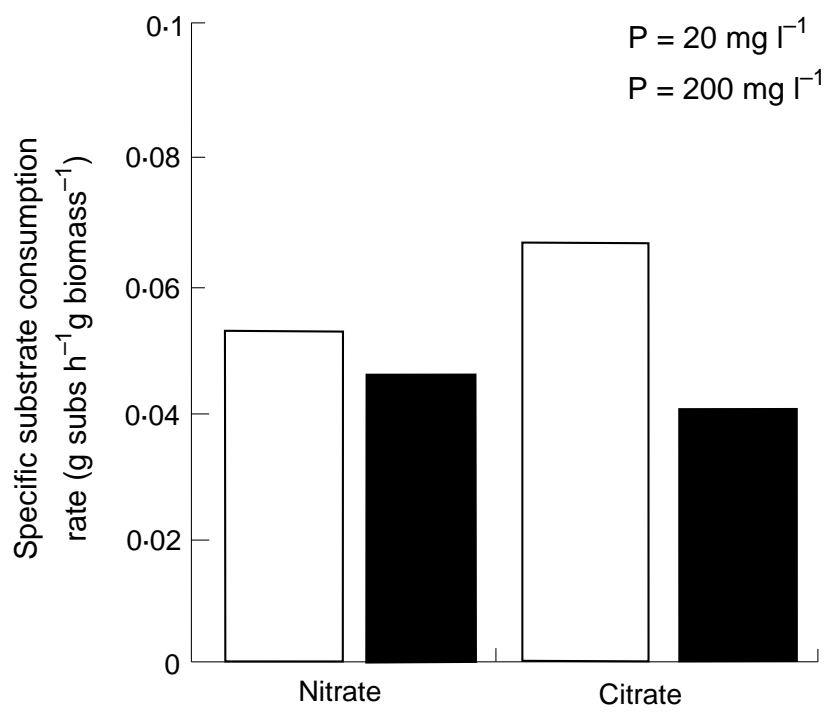

Fig. 2 Specific substrate consumption of planktonic cells of Alcaligenes denitrificans, for $\mathrm{C} / \mathrm{N}=2$ and under two phosphorous concentrations: $(\boldsymbol{\square}), \mathrm{P}=20 \mathrm{mg} \mathrm{l}^{-1}$; $\left.\square\right), \mathrm{P}=200 \mathrm{mg} \mathrm{l}^{-1}$

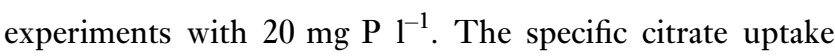
rate was slightly higher for the higher phosphorous concentration studied. Specific nitrate consumption was almost the same for both phosphorous concentrations. From the results, it was concluded that a carbon/nitrogen ratio of 2 was most appropriate. Therefore, the experiments with cells in planktonic form and as a biofilm were performed with this $\mathrm{C} / \mathrm{N}$ ratio.

In the assays with cells of Alc. denitrificans in biofilm form, with $200 \mathrm{mg} \mathrm{P}^{-1}$, citrate was completely consumed in 3-4 $\mathrm{h}$ and nitrate removal attained $85 \%$. In the experiments with $20 \mathrm{mg} \mathrm{P}^{-1}$, nitrate consumption was, on average, $72 \cdot 5 \%$ and citrate was completely consumed in $4-6 \mathrm{~h}$. In this case, nitrate and citrate removal was higher for the higher phosphorous concentration (Fig. 3). Comparing these results with those obtained with planktonic cells, in terms of nitrate consumption it was verified that the activity of cells in biofilm form is almost 10-fold higher than that of planktonic cells, whereas it is 14 -fold higher when citrate consumption is considered.

\section{DISCUSSION}

The activity of cells of Alc. denitrificans, when grown in suspension in liquid medium and in biofilm form on a solid surface, was compared. These results showed that specific activity in terms of citrate and nitrate consumption was significantly higher for the cells in biofilm form. This is in accordance with the results of several authors who have reported that bacteria associated with a solid surface exhibit higher uptake rates (Paerl and Merkel 1982; McFeters et al.

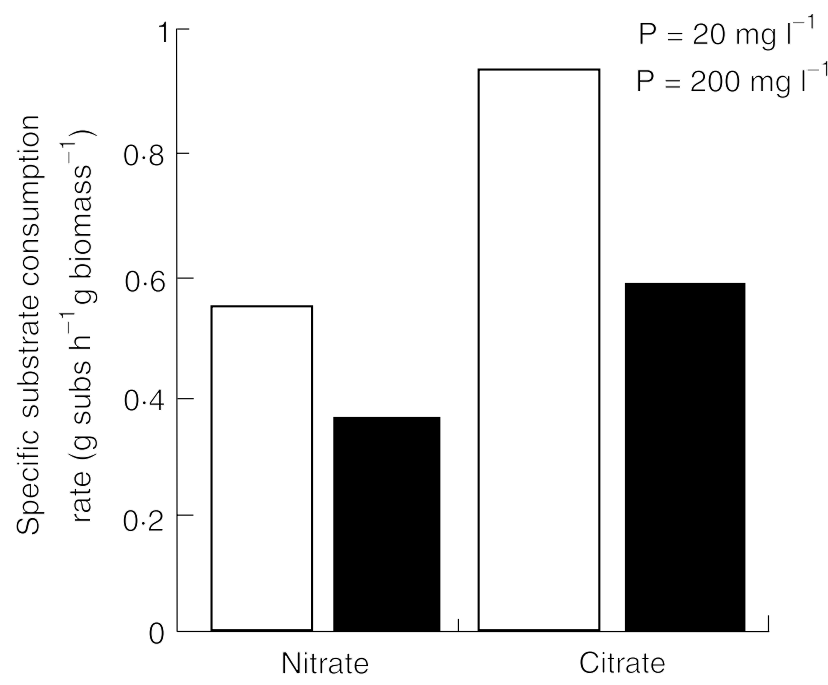

Fig. 3 Specific substrate consumption for biofilm cells of Alcaligenes denitrificans, under two phosphorous concentrations (ם), $\mathrm{P}=20 \mathrm{mg} \mathrm{l}^{-1} ;(\square), \mathrm{P}=200 \mathrm{mg} \mathrm{l}^{-1}$

1990). It is well known that cells grown on solid surfaces have different properties from those of planktonic cells. One reason for this is that bacteria adhering to a surface are exposed to environmental conditions not found in the aqueous phase. These different conditions include lower $\mathrm{pH}$ levels (resulting from proton accumulation), altered water structure (and hence, altered viscosity and/or water availability) and altered rates of gas exchange (Marshall and Goodman 1994). According to these authors, as a result of changes in environmental conditions, it is feasible that different sites of genes would be 'switched on' or 'switched off'.

With regard to the effect of increasing phosphorous concentration, there was no evident increase in the specific activity of the planktonic cells. On the other hand, the substrate uptake rate of the biofilm displayed a marked dependence on phosphorous concentration.

\section{ACKNOWLEDGEMENTS}

The authors fully acknowledge the financial support provided by Instituto de Biotecnologia e Química Fina (IBQF) and PRAXIS XXI through grant BD/9121/96.

\section{REFERENCES}

APHA (1995) Standard Methods for the Examination of Water and Wastewater. Washington D.C.: American Public Health Association. Blaszczyk, M. (1983) Effect of various sources of organic carbon and high nitrite and nitrate concentrations on the selection of denitrifying bacteria. II. Continuous cultures in packed bed reactors. Acta Microbiologica Polonica 32, 65-71. 
Caldwell, D.E., Korber, D.R. and Lawrence, J.R. (1992) Confocal laser microscopy and digital image analysis in microbial ecology. Advances in Microbial Ecology 12, 1-67.

Gayle, B.P., Boardman, G.D., Sherrard, J.H. and Benoit, R.E. (1989) Biological denitrification of water. Fournal of Environmental Engineering 115, 930-943.

Marshall, K.C. and Goodman, A.E. (1994) Effects of adhesion on microbial cell physiology. Colloids Surfaces B: Biointerfaces 2, 1-7.

Máteju, V., Cizinská, S., Krejcí, J. and Janoch, T. (1992) Biological water denitrification - a review. Enzyme Microbiology and Technology $14,170-183$.

McCarty, P.L., Beck, L. and Amant, P.S. (1969) Biological denitrification of wastewaters by addition of organic materials. In Proceedings of the 24th Purdue Industrial Waste Conference, Purdue University, Indiana, USA. pp. 1271-1285.

McCoy, W.F. and Costerton, J.W. (1982) Fouling biofilm development in tubular flow systems. Developments in Industrial Microbiology 23, $551-558$.
McFeters, G.A., Egli, T., Wilberg, E. et al. (1990) Activity and adaptation of nitrilotriacetate (NTA)-degrading bacteria: field and laboratory studies. Water Research 24, 875-881.

Paerl, H.W. and Merkel, S.M. (1982) Differential phosphorus assimilation in attached vs unattached microorganisms. Archiv für Hydrobiologie 93, 125-134.

Reisinger, C., Braun, R. and Moser, A. (1989) Cybernetic and technical aspects for advanced biological drinking water treatment. In Workshop-Strategies for Closed Cycle Production, Department of Biotechnology, Technical University of Graz, Austria, p. 10.

Robertson, L.A., Cornelisse, R., de Vos, P., Hadioetomo, R. and Kuenen, J.G. (1989) Aerobic denitrification in various heterotrophic nitrifiers. Antonie van Leeumenhoek. 56, 289-299.

Vandevivere, P. and Kirchman, D.L. (1993) Attachment stimulates exopolysaccharide synthesis by a bacterium. Applied and Environmental Microbiology 59, 3280-3286. 